Architekturpolitik in Finnland

Wie Baukulturelle Bildung gelingen kann 



\section{Turit Fröbe}

\section{Architekturpolitik in Finnland}

Wie Baukulturelle Bildung gelingen kann 
